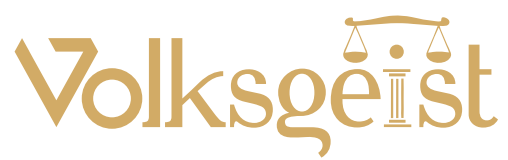

ISSN Print 2615-5648

ISSN Online 2615-174X
Kantor Editor : Lantai 2 Fakultas Syariah UIN SAIZU Purwokerto

Jl. A. Yani No. 40A Purwokerto Jawa Tengah 531226 Indonesia

Telp.

E-Mail

: +62 281635624 Fax. +62 281636653

Website
: Volksgeist@uinsaizu.ac.id

: http://ejournal.uinsaizu.ac.id/index.php/ Volksgeist

\title{
Kedudukan Majelis Kehormatan Disiplin Kedokteran Indonesia dalam Penyelesaian Sengketa Medis
}

\author{
Kastania Lintang, ${ }^{1}$ Hasnati, Bahrun Azmi ${ }^{2}$ \\ ${ }^{1,2}$ Fakultas Hukum, Universitas Lancang Kuning \\ ${ }^{1}$ Email: kastanialintang94@gmail.com
}

\begin{abstract}
Abstrak
Artikel ini bertujuan untuk menganalisis kedudukan Majelis Kehormatan Disiplin Kedokteran Indonesia (MKDKI) dalam Penyelesaian Sengketa Medis. Penelitian ini menggunakan metode penelitian yuridis normatif dengan pendekatan perundang-undangan dan pendekatan konseptual. Sengketa medis akibat dugaan pelanggaran disiplin kedokteran seharusnya diselesaikan melalui Majelis Kehormatan Disiplin Kedokteran Indonesia, namun saat ini masih ada sengketa medis yang dilaporkan ke pengadilan tanpa melalui Majelis Kehormatan Dokter Kedokteran Indonesia. Hasil penelitian ini menunjukkan bahwa masih dijumpai ketidakpastian hukum terhadap penyelesaian sengketa medis antara dokter dan pasien, karena kata "dapat" yang tercantum pada ayat (1) peraturan tentang praktek kedokteran dapat bermakna bahwa pengaduan kepada Majelis Kehormatan Disiplin Kedokteran Indonesia tersebut mungkin saja dapat dilakukan ataupun tidak dilakukan. Sedangkan pada ayat (3) mengatakan bahwa tidak menutup kemungkinan untuk menyelesaikan sengketa medis melalui pengadilan, yang dapat menyebabkan penyelesaian sengketa medis dapat saja dilakukan melalui pengadilan.
\end{abstract}

Kata Kunci: Praktik kedokteran; sengketa medis; MKDKI

\begin{abstract}
This article aims to analyze the position of the Indonesian Medical Disciplinary Board (MKDKI) in the settlement of medical disputes. This study uses a normative juridical research method with a statute approach and a conceptual approach. Medical disputes due to alleged violations of medical discipline should be resolved through the Indonesian Medical Disciplinary Board, however currently there are still medical disputes that are reported to the court without going through the Indonesian Medical Disciplinary Board. The results of this study show that, there is still legal uncertainty regarding the resolution of medical disputes between doctors and patients, because the word "can" contained in paragraph (1) of the regulation on medical practice could mean that the complaint to the Indonesian Medical Disciplinary Board may or may not be made. Whereas in paragraph (3) it is stated that it is possible to resolve medical disputes through the courts, which can cause medical dispute resolution to be carried out through the courts directly.
\end{abstract}

Keywords: Medical practice; medical dispute; MKDKI 


\section{Sejarah Artikel}

Dikirim: 30 Agustus 2021

Direview: 08 November 2021

Diterima: 19 November 2021

Diterbitkan: 24 November 2021

\section{PENDAHULUAN}

Awalnya hubungan dokter dan pasien merupakan hubungan vertikal yaitu paternalistik, dimana hubungan tersebut seperti bapak dan anak yang berprinsip father knows best. Pada hubungan vertikal ini dokter bertindak sebagai bapak yang baik dan cermat, dimana kedudukan dokter lebih tinggi daripada pasien karena dokter dianggap mengetahui segalanya. ${ }^{1}$ Seiring meningkatnya taraf pendidikan dan IPTEK, maka hubungan dokter dan pasien terjadi perubahan dalam segi tingkat pemahaman mengenai kesehatan di masyarakat. ${ }^{2}$ Sadarnya pasien terhadap hak dan kewajiban yang merupakan hubungan hukum antara dokter dan pasien, dapat menimbulkan potensi terjadinya sengketa medis. Maka diperlukan pemahaman mengenai hubungan hukum antara dokter dan pasien. Dengan adanya hubungan hukum, maka akan melahirkan perbuatan hukum yang menimbulkan adanya akibat hukum. Akibat hukum yang timbul tidak dapat dipisahkan mengenai siapa yang bertanggung jawab dan sejauh apa tanggung jawab tersebut dapat diberikan. $^{3}$

\footnotetext{
1 Retno Harjanti Hartiningsih, "POLA HUBUNGAN HUKUM ANTARA DOKTER DAN PASIEN," MAKSIGAMA 14, no. 1 (July 27, 2020): 4960, https://doi.org/10.37303/maksigama.v14i1.88.

2 Ukilah Supriyatin, "HUBUNGAN HUKUM ANTARA PASIEN DENGAN TENAGA MEDIS (DOKTER) DALAM PELAYANAN KESEHATAN," Jurnal Ilmiah Galuh Justisi 6, no. 2 (November 19, 2018): 184-94, https://doi.org/10.25157/jigj.v6i2.1713.

3 Yussy A. Mannas, "Hubungan Hukum Dokter dan Pasien Serta Tanggung Jawab Dokter Dalam Penyelenggaraan Pelayanan Kesehatan," JURNAL CITA HUKUM 6, no. 1 (June 23, 2018): 163-82, https://doi. org/10.15408/jch.v6i1.8274.
}

Kata sengketa sering ditemukan dalam kehidupan sehari-hari, namun dalam kasus medis kata sengketa sangat jarang digunakan, karena masyarakat hanya mengetahui istilah malapraktik. ${ }^{4}$ Sengketa medis merupakan sengketa yang terjadi antara pasien ataupun keluarga pasien dengan tenaga kesehatan, maupun fasilitas pelayanan kesehatan. Biasanya yang dipermasalahakan adalah hasil akhir dari pelayanan kesehatan tanpa memperhatikan prosesnya. $^{5}$ Penyelesaian sengketa medis terdapat dalam Pasal 66 ayat (1) UndangUndang Nomor 29 Tahun 2004 tentang Praktik Kedokteran yang mengatakan bahwa: "Setiap orang yang mengetahui atau kepentingannya dirugikan atas tindakan dokter atau dokter gigi dalam menjalankan praktik kedokteran dapat mengadukan secara tertulis kepada Ketua Majelis Kehormatan Disiplin Kedokteran Indonesia". 6

Namun saat ini masih ada beberapa permasalahan sengketa medis yang dilaporkan langsung ke pihak kepolisian, seperti pada kasus yang dikutip dari kompas.com, seorang dokter spesialis anak berinisial AO yang bekerja di RS MM, Kota Bekasi, dilaporkan ke Polda Metro Jaya pada Selasa 28 Maret 2017. Dokter AO dianggap lalai menyiapkan alat saat emergency sehingga mengakibatkan bayi bernama DMCP yang berusia 3 bulan meninggal dunia. Pengacara Ira, Afrizal,

4 Mohammad Irfan and Syamsul Hidayat, "SENGKETA MEDIK DAN ALTERNATIF PENYELESAIANNYA DALAM HUKUM POSITIF DI INDONESIA," Jurnal IUS Kajian Hukum dan Keadilan 6, no. 3 (December 26, 2018): 482-92, https://doi. org/10.29303/ius.v6i3.572.

${ }^{5}$ Muhammad Afiful Jauhani, Dilema Kapabilitas Dan Imparsialitas Dokter Sebagai Mediator Sengketa Medis (Surabaya: Scopindo Media Pustaka, 2020).

6 Jovita Irawati, "INKONSISTENSI REGULASI DI BIDANG KESEHATAN DAN IMPLIKASI HUKUMNYA TERHADAP PENYELESAIAN PERKARA MEDIK DI INDONESIA," Law Review 19, no. 1 (July 2019): 54-76, https://doi.org/10.19166/ lr.v19i1.1551. 
menyebut dokter AO diduga melakukan tindak pidana karena melanggar Pasal 359 KUHP jo 84 ayat 2 Undang-Undang Nomor 36 Tahun 2014 tentang Tenaga Kesehatan. Laporan orang tua dari Bayi DMCP telah diterima Polda Metro Jaya. $^{7}$

Selain itu, terdapat kasus sengketa medis, yaitu RS AB dan Dokter YWA terbukti bersalah oleh Pengadilan Negeri Bekasi pada akhir Juni 2016 dan digugat membayar kerugian materil sebesar Rp205.500.000,00 akibat meninggalnya Falya yang diduga karena pemberian antibiotik oleh Dokter YWA. RS AB mengajukan banding dan Hakim Banding mengatakan bahwa kasus ini terlalu cepat diajukan ke Pengadilan Negeri, sehingga masih bersifat prematur dan putusan Pengadilan Negeri Bekasi tidak dapat dipertahankan dan dibatalkan, dengan pertimbangan perkara belum disidang oleh Majelis Kehormatan Disiplin Kedokteran Indonesia (MKDKI). ${ }^{8}$

Kasus sengketa medis terjadi di Palu yang menimpa dokter $\mathrm{H}$ yang merupakan spesialis kandungan di RSU A Palu. Jaksa Penuntut Umum menuntut pidana penjara selama 1 (satu) tahun terhadap dokter $\mathrm{H}$ yang merupakan terdakwa malapraktik dan menyebakan pasien Nur Indah Restuwati meninggal dunia setelah melahirkan anak ketiganya pada Bulan Agustus 2016. Terdakwa diduga melanggar pasal Pasal 359 KUH Pidana Jo. 361 KUH Pidana. Beruntungnya oleh Pengadilan Negeri Palu dokter $\mathrm{H}$ divonis bebas setelah kesus ini berlangsung selama 1 tahun karena Jaksa

7 Nursita Sari, "Bayinya Meninggal Di RS, Ibu Ini Laporkan Dokter Di Bekasi Ke Polisi," Kompas. Com, March 28, 2017, https://megapolitan.kompas.com/ $\mathrm{read} / 2017 / 03 / 28 / 15185181 /$ bayinya.meninggal.di.rs.ibu. ini.laporkan.dokter.di.bekasi.ke.polisi?page=all.

8 Pebriansyah Ariefana and Ummi Hadyah Saleh, "Keluarga Korban Malpraktik Falya Raafani Blegur Mengadu Ke KY," Suara.Com, February 3, 2017, https:// www.suara.com/news/2017/02/03/140634/keluargakorban-malpraktik-falya-raafani-blegur-mengadu-keky?page=all.
Penuntut Umum tidak dapat membuktikan tuntutannya. ${ }^{9}$

Kasus sengketa medis juga terjadi pada dr. TS dan dr. FMK di RS K Jakarta Pusat pada bulan Februari 2010, mengakibatkan RS K diadukan ke MKDKI pada tanggal 10 Agustus 2010. MKDKI mengeluarkan keputusan pada pengaduan Siti Chomsatun bernomor: No. 43/P/MKDKI/VIII/2010. Berdasarkan putusan MKDKI tersebut, Siti Chomsatun melakukan Gugatan Perbuatan Melawan Hukum kepada RS K ke Pengadilan Negeri Jakarta Pusat. ${ }^{10}$

Dokter mungkin saja melakukan kelalaian dalam menjalankan profesinya, baik sengaja (dolus), maupun tidak sengaja (lalai, culpa), namun masyarakat akan memandang kesalahan tersebut sebagai akibat malapraktik medis, sehingga dapat membuat pasien melaporkan kasus tersebut melalui jalur hukum. ${ }^{11}$ Setiap melakukan tindakan kedokteran akan selalu ada risiko yang menyertainya baik itu merupakan risiko yang kecil atau risiko besar sekalipun. ${ }^{12}$ Pada kedokteran tidak mengenal tindakan malapraktik medis, karena malapraktik tersebut merupakan tindakan yang sengaja dilakukan. ${ }^{13}$ Regulasi normatif mengenai penyelesaian sengketa medis yang terdapat dalam Pasal 66 ayat (1) Undang-Undang Nomor 29 Tahun 2004 tentang Praktik Kedokteran mengatakan bahwa apabila pasien merasa dirugikan ter-

9 Radar Sulteng, "Dugaan Malapraktik, Dr Heryani Menangis Bacakan Pembelaan Pribadinya," May 31, 2018, https://radarsulteng.id/dugaan-malapraktik-drheriyani-menangis-bacakan-pembelaan-pribadinya/.

${ }^{10}$ Sutan Remy Sjahdeini, HUKUM KESEHATAN TENTANG "HUKUM MALAPRAKTIK TENAGA MEDIS" Jilid 2, Cetakan 1 (Bogor: PT. Penerbit IPB Press, 2020).

11 Risma Situmorang, Tanggungjawab Hukum Dokter Dalam Malpraktik (Bandung: CV Cendekia Press, 2020).

12 Ontran Sumantri Riyanto, Pembentukan Pengadilan Khusus Medis, Cetakan Pertama (Surabaya: Deeppublish Publisher, 2018).

13 Sabrina Hidayat, Pembuktian Kesalahan: Pertanggungjawaban Pidana Dokter Atas Dugaan Malpraktik Medis (Scopindo Media Pustaka, 2020). 
hadap tindakan kedokteran yang dilakukan oleh dokter, maka pasien tersebut dapat melaporkannya ke Majelis Kehormatan Disiplin Kedokteran Indonesia. Sehingga, idealnya penyelesaian permasalahan sengketa medis sebaiknya diselesaikan melalui prosedur non-litigasi terlebih dahulu sebelum dilakukan upaya lanjutan seperti gugatan perdata maupun pidana. ${ }^{14}$

Berdasarkan Putusan Mahkamah Konstitusi Republik Indonesia dalam Nomor 14/ PUU-XII/2014, penyelesaian sengketa medis juga tercantum pada Pasal 66 ayat (3) UndangUndang Nomor 29 Tahun 2004 tentang Praktik Kedokteran mengatakan bahwa apabila setiap orang yang merasakan dirugikan atas tindakan kedokteran yang diterimanya, tidak menghilangkan haknya untuk melaporkan adanya dugaan tindak pidana kepada pihak yang berwenang dan/atau menggugat kerugian perdata ke pengadilan.

Menurut Jovita Irawati adanya inkonsistensi regulasi di bidang kesehatan yang membahas tentang pengaturan hak pasien dalam penyelesaian sengketa medis membuat terbukanya peluang sengketa medis diselesaikan melalui berbagai jalur. Adanya ketidakharmonisan regulasi di bidang kesehatan dapat menimbulkan kerugian terhadap pasien dan dokter, karena terdapat inkonsistensi norma pengaturan, terkhususnya dalam hakhak pasien. ${ }^{15}$

Setyo Sugiharto mengemukakan bahwa untuk mengatasi masalah sengketa medis sebaiknya tidak memakan waktu, biaya yang mahal dan menempuh prosedur yang panjang, maka penyelesaian sengketa medis di luar pengadilan disarankan. ${ }^{16}$ Pada tesis yang

\footnotetext{
${ }^{14}$ Irawati, "INKONSISTENSI REGULASI DI BIDANG KESEHATAN DAN IMPLIKASI HUKUMNYA TERHADAP PENYELESAIAN PERKARA MEDIK DI INDONESIA."

${ }^{15}$ Irawati.

${ }^{16}$ Setyo Sugiharto, "Negosiasi Sebagai Alternatif Penyelesaian Sengketa Medik Dalam Perspektif
}

ditulis oleh Moh. Fadly dengan judul: Putusan MKDKI Sebagai Bukti Permulaan dalam Proses Penyidikan Terhadap Dokter yang dilaporkan dalam Sengketa Medik mengatakan bahwa MKDKI merupakan lembaga yang memiliki peranan penting dalam menerapkan disiplin kedokteran. MKDKI merupakan lembaga yang berwenang menentukan ada atau tidaknya kesalahan yang dilakukan dokter yang dinyatakan bersalah, meskipun Pasal 29 Undang-Undang Nomor 36 Tahun 2009 tentang Kesehatan mengatakan bahwa apabila tenaga kesehatan diduga melakukan kelalaian dalam menjalankan profesinya, harus diselesaikan terlebih dahulu melalui mediasi. ${ }^{17}$

Menurut Andryawan kedudukan dari MKDKI masih menimbulkan permasalahan hukum, di mana salah satunya MKDKI sering tidak produktif akibat adanya hambatan yang dilakukan oleh KKI dan ada beberapa penegakan disiplin yang diputuskan oleh MKDKI dibatalkan di Pengadilan Tata Usaha Negara. Sehingga membuat penegakan disiplin kedokeran tidak ada kepastian. Padahal penegakan terhadap disiplin kedokteran yang diputuskan oleh MKDKI merupakan keputusan yang bersifat final dan mengikat. ${ }^{18}$ Selain itu, penelitian Arif Dian Santoso yang berjudul Penyelesaian Sengketa Medik Melalui Mediasi oleh MKDKI untuk dapat Menjamin Keadilan dalam Hubungan Dokter dan Pasien. Menunjukkan bahwa menyelesaikan sengketa medis lebih dianjurkan melalui proses mediasi, yang mana awal hubungan ini adalah

Pemenuhan Hak Pasien" (Thesis, Malang, Universitas Muhammadiyah Malang, 2020).

${ }^{17}$ Moh. Fadly, "Putusan MKDKI Sebagai Bukti Permulaan Dalam Proses Penyidikan Terhadap Dokter Yang Dilaporkan Dalam Sengketa Medik" (Thesis, Yogyakarta, Univesitas Islam Indonesia, 2017).

${ }^{18}$ Andryawan, "Kedudukan Majelis Kehormatan Disiplin Kedokteran Indonesia (MKDKI) Dan Konsil Kedokteran Indonesia (KKI) Dalam Penegakan Disiplin Kedokteran Di Indonesia (Studi Putusan Mahkamah Agung RI Nomor: 298K/TUN/2012)" (Thesis, Jakarta, Universitas Tarumanegara, 2015). 
kepercayaan dan mediasi bukan dilaksanakan oleh MKDKI, karena tugas MKDKI yaitu mengawasi disiplin kedokteran, dan putusan MKDKI dapat menjadi dasar untuk bahan mediasi yang bisa dijadikan tolak ukur dalam penyelesaian sengketa medis. ${ }^{19}$

Dikarenakan sengketa medis dapat saja diselesaikan secara langsung melalui jalur litigasi atau pengadilan, maka berdasarkan uraian yang telah dijabarkan di atas, maka artikel ini bertujuan menjawab Kedudukan Majelis Kehormatan Disiplin Kedokteran Indonesia dalam Penyelesaian Sengketa Medis.

Penelitian ini menggunakan metode penelitian hukum yuridis normatif yang menggunakan data sekunder untuk dijadikan sumber dalam penulisan artikel. ${ }^{20}$ Bahan hukum pada penelitian ini bersumber dari berbagai peraturan perundang-undangan, dan akan dipertajam dengan pendekatan perundangundangan (statute approach) dan pendekatan konseptual (conseptual approach), yang dilakukan dengan cara menggunakan konsep dari pemikiran ahli ataupun pakar terhadap bidang yang sesuai dengan masalah yang akan dibahas. ${ }^{21}$ Penelitian ini menggunakan metode analisis data kualititif untuk menganalisa bahan hukum yang telah dikumpulkan dan akan disampaikan secara deskriptif, yaitu dengan menggambarkan Kedudukan Majelis Kehormatan Disiplin Kedokteran Indonesia dalam Penyelesaian Sengketa Medis.

19 Arif Dian Santoso, "PENYELESAIAN SENGKETA MEDIK MELALUI MEDIASI OLEH MAJELIS KEHORMATAN DISIPLIN KEDOKTERAN INDONESIA (MKDKI) UNTUK DAPAT MENJAMIN KEADILAN DALAM HUBUNGAN DOKTER DAN PASIEN," Jurnal Pasca Sarjana Hukum UNS 7, no. 1 (2019): 29-38.

${ }^{20}$ Muhaimin, Metode Penelitian Hukum, Cetakan Pertama (NTB: Mataram University Press, 2020).

${ }^{21}$ Bachtiar, Metode Penelitian Hukum, Cetakan Pertama (UNPAM PRESS, 2019).

\section{PEMBAHASAN}

\section{Sengketa Medis}

Sengketa berarti perselisihan atau konflik, konflik muncul akibat adanya pertentangan antara orang, kelompok, ataupun organisasi pada suatu permasalahan. Sengketa dapat terjadi pada individu atau kelompok yang memiliki hubungan ataupun kepentingan yang sama terhadap objek yang dapat menimbulkan sebuah akibat hukum antara satu dengan yang lain. Sehingga sebuah konflik dapat menjadi sengketa apabila konflik itu tidak mampu diselesaikan secara baik oleh kedua pihak. Berdasarkan adanya hubungan dokter dan pasien terhadap pelayanan medis, maka konflik mungkin saja dapat timbul apabila pelayanan medis yang diberikan oleh dokter tidak sesuai dengan harapan. Adanya kekecewaan terhadap harapan yang tidak terpenuhi dan disertai tidak adanya komunikasi efektif dapat memicu timbulnya konflik atau sengketa medis. Sengketa medis dapat timbul apabila terdapat tuntutan kepada dokter, pengaduan pada polisi, ataupun adanya gugatan ke pengadilan. ${ }^{22}$

Adanya pelanggaran yang bersifat perbuatan melawan hukum dalam melaksanakan profesi dapat menimbulkan ketidakpuasan dan kerugian pada pihak pasien, hal tersebut dapat terjadi jika bagian dari transaksi terapeutik tidak terpenuhi ataupun dilanggar oleh dokter. Pelanggaran yang mungkin dilakukan dokter ketika melaksanakan profesi medis dapat terdiri dari, pelanggaran terhadap etik profesi, pelanggaran terhadap disiplin profesi, pelanggaran administrasi, pelanggaran hukum perdata dan pidana. Sengketa medis yang dipermasalahkan biasanya hasil akhir dari pelayanan kesehatan tanpa memperhatikan prosesnya. Sedangkan pada hukum kesehatan, dokter hanya bertanggung jawab terhadap proses

${ }^{22}$ Widodo Tresno Novianto, SENGKETA MEDIK Pergulatan Hukum Dalam Menentukan Unsur Kelalaian Medik, Cetakan 1 (Surakarta: Penerbitan dan Percetakan UNS (UNS Press, 2017). 
ataupun upaya yang dilakukan (inspanning verbintenis), dan tidaklah menjamin hasil akhir (resultaat verbintenis). Sehingga apabila belum ada putusan yang dikeluarkan oleh peradilan profesi, maka istilah malapraktik medis menjadi tidak tepat. Hal ini dikarenakan perlu adanya pertimbangan terhadap logika hukum dan juga logika medis untuk dapat menentukan apakah tindakan medis tersebut dapat dikategorikan malapraktik medis. ${ }^{23}$

Pelayanan kesehatan diikuti adanya hubungan hukum yang terbentuk antara dokter dan pasien mungkin saja terjadi pengabaian dari pihak pasien sehingga dapat menimbulkan konflik atau sengketa. Konflik dapat terdiri dari $^{24}$ :

1. Pra konflik yang merupakan sebuah keadaan yang bermula dari rasa ketidakpuasan seseorang dikarenakan perlakuan yang tidak adil

2. Konflik merupakan sebuah keadaan dimana para pihak mengetahui adanya perselisihan diantara mereka.

3. Sengketa meruapkan sebuah keadaan dimana konflik dinyatakan didepan umum atau dengan mengikutkan pihak ketiga.

Jika dihubungkan dengan hubungan antara dokter dan pasien, sengketa medis dapat bermula dari perasaan yang tidak puas terhadap salah satu pihak oleh karena pihak yang lain tidak dapat memenuhi prestasi sesuai dengan yang dijanjikan atau adanya wanprestasi. Salah satu penyebab timbulnya sengketa medis yaitu pelaksanaan pemberian informasi belum sesuai dengan harapan. Dokter belum sepenuhnya dapat melaksanakan kewajibannya dalam memberikan informasi yang lengkap terhadap pelayanan kesehatan ataupun tindakan

\footnotetext{
${ }^{23}$ Novianto.

24 Santoso, "PENYELESAIAN SENGKETA
} MEDIK MELALUI MEDIASI OLEH MAJELIS KEHORMATAN DISIPLIN KEDOKTERAN INDONESIA (MKDKI) UNTUK DAPAT MENJAMIN KEADILAN DALAM HUBUNGAN DOKTER DAN PASIEN." medis yang akan dilakukannya kepada pasien, sedangkan pasien belum sepenuhnya mengetahui haknya. Bahkan sekarang ini kasus terhadap ketidakpuasan pasien terhadap pelayanan kesehatan tampak meningkat.

Menurut Afendra Eka Putra, kurangnya informasi dalam melaksanakan praktik kedokteran dapat disebabkan oleh kesibukan ataupun rutinitas dari pekerjaan dokter yang menyita waktu, sehingga mengakibatkan dokter tidak mempunyai waktu yang cukup untuk menyampaikan seluruh informasi. Selain itu, banyaknya jumlah pasien yang ditangani membuat dokter menjadi jenuh dalam memberikan informasi secara lengkap, dan apabila dokter terlalu banyak memberikan informasi kepada pasien akan menimbulkan rasa takut dan tertekan pada pasien yang dapat saja memperburuk proses penyembuhan atau bahkan mengakibatkan penolakan tindakan kedokeran dari pasien. ${ }^{25}$

Dokter dapat saja menghindari timbulnya sengketa medis terhadap pasien dengan cara mengurangi kesenjangan informasi antar dokter dan pasien, meningkatkan kepercayaan pasien terhadap dokter dengan memperlakukan pasien secara rasional, memberikan informasi yang jujur, memastikan pasien mau mematuhi saran dokter, mengurangi kekerasan moral antara dokter dan pasien dengan selalu mengevaluasi diagnosis dan memberikan terapi sehingga dapat terbentuk hubungan yang harmonis dan hubungan yang sehat antara dokter dan pasien. ${ }^{26}$

Sengketa medis yang timbul dapat dapat diselesaikan melalui: Majelis Kehormatan Etik Kedokteran (MKEK) merupakan lembaga

${ }^{25}$ Afendra Eka Saputra, "PERLINDUNGAN HUKUM BERBASIS ' INFORMED CONSENT , ATAS PELAKSANAAN PROGRAM IMUNISASI DI INDONESIA," Rechtsregel : Jurnal Ilmu Hukum 1, no. 2 (January 29, 2019): 235-54, https://doi.org/10.32493/ rjih.v1i2.2216.

26 Juliana Susanti Gunawan, "Living Law Transplantation In Construction Criminal Medical Law," Nagari Law Review 4, no. 2 (April 2021): 188-99. 
yang akan menangani pelanggaran terhadap etika kedokteran yang dibentuk oleh Organisasi Profesi Ikatan Dokter Indonesia (IDI) ${ }^{27}$; Majelis Kehormatan Disiplin Kedokteran Indonesia (MKDKI) merupakan lembaga yang menangani pelanggaran terhadap disiplin kedokteran yang berada di bawah naungan Konsil Kedokteran Indonesia; Pengadilan merupakan suatu badan ataupun instansi resmi yang menjalankan sistem peradilan yang berupa memeriksa, mengadili, serta memutuskan perkara; dan di luar pengadilan secara negosiasi ataupun mediasi. $^{28,29}$

\section{Majelis Kehormatan Disiplin Kedokteran Indonesia dalam Penyelesaian Sengketa Medis}

Majelis Kehormatan Disiplin Kedokteran Indonesia (MKDKI) merupakan lembaga yang memiliki wewenang dalam menentukan apakah ada atau tidaknya kesalahan dalam menerapkan disiplin kedokteran, dan juga memiliki fungsi untuk dapat menegakkan aturan yang mewajibkan untuk dipatuhi oleh dokter ketika menyelenggarakan praktik kedokteran. ${ }^{30}$ Anggota MKDKI terdiri dari dokter yang merupakan perwakilan dari organisasi profesi, asosiasi rumah sakit, dan ahli hukum. Anggota MKDKI terdiri dari tiga orang dokter dan tiga orang dokter gigi dari organisasi profesi masing

${ }^{27}$ Majelis Kehormatan Etik Kedokteran, Pedoman Organisasi Dan Tatalaksana: Majelis Kehormatan Etik Kedokteran Ikatan Dokter Indonesia (Samarinda: MKEK IDI, 2018).

28 Santoso, "PENYELESAIAN SENGKETA MEDIK MELALUI MEDIASI OLEH MAJELIS KEHORMATAN DISIPLIN KEDOKTERAN INDONESIA (MKDKI) UNTUK DAPAT MENJAMIN KEADILAN DALAM HUBUNGAN DOKTER DAN PASIEN."

29 Gunawan, "Living Law Transplantation In Construction Criminal Medical Law."

${ }^{30}$ Khairunnisa Nugrianti and Ratna Herawati, "TINJAUAN YURIDIS TUGAS DAN WEWENANG MAJELIS KEHORMATAN DISIPLIN KEDOKTERAN INDONESIA" 6, no. 2 (2017): 1-18. masing, satu orang dokter dan dokter gigi mewakili asosiasi rumah sakit serta tiga orang dari sarjana hukum. Hal ini bertujuan agar dapat memberikan kenetralan dalam melaksanakan peran MKDKI tersebut. ${ }^{31}$

Berdasarkan Pasal 3 Peraturan Konsil Kedokteran Indonesia Nomor 3 Tahun 2011 tentang Organisasi dan Tata Kerja Majelis Kehormatan Disiplin Kedokteran Indonesia dan Majelis Kehormatan Disiplin Kedokteran di Tingkat Provinsi menyatakan bahwa dalam melaksanakan penegakan disiplin kedokteran MKDKI bertugas untuk:

1. Menerima pengaduan, melakukan pemeriksaan, serta membuat keputusan terhadap kasus adanya dugaan pelanggaran disiplin profesional dokter serta dokter gigi yang telah diajukan; dan

2. Melakukan penyusunan terhadap pedoman tata cara menangani kasus adanya dugaan pelanggaran terhadap disiplin profesional dokter serta dokter gigi.

Selain itu, MKDKI juga mempunyai wewenang yang telah diatur dalam Pasal 5 Peraturan Konsil Kedokteran Indonesia Nomor 3 Tahun 2011 tentang Organisasi dan Tata Kerja Majelis Kehormatan Disiplin Kedokteran Indonesia dan Majelis Kehormatan Disiplin Kedokteran Indonesia di Tingkat Provinsi, yaitu MKDKI memiliki wewenang dalam menyusun tata cara penanganan kasus adanya dugaan pelanggaran terhadap disiplin profesional dokter serta dokter gigi; melakukan penyusunan buku pedoman dalam pelaksanaan tugas MKDKI serta MKDKI-P; penerimaan pengaduan adanya dugaan pelanggaran terhadap disiplin profesional dokter serta dokter gigi, dan menerima apabila terdapat permohonan banding; melakukan penolakan

31 Deri Mulyadi, “Alternatif Penyelesaian Sengketa Kelalaian Medik yang Berkeadilan di Indonesia," Journal of Multidisciplinary Studies 11, no. 2 (December 2020): 126-38. 
terhadap pengaduan yang bukan merupakan yurisdiksi MKDKI serta menolak apabila terdapat permohonan banding; melaksanakan penanganan kasus adanya dugaan pelanggaran terhadap disiplin profesional dokter serta dokter gigi dengan cara melakukan investigasi, klarifikasi, serta pemeriksaan disiplin, selain itu meminta dan memeriksa rekam medis maupun dokumen lainnya yang berasal dari beberapa pihak berhubungan dengan tingkat pertama serta tingkat banding; melakukan pemanggilan terhadap pengadu, teradu, saksi-saksi, maupun ahli yang berhubungan dengan pengaduan agar dapat didengar keterangannya; membuat keputusan ada atau tidaknya pelanggaran disiplin profesional dokter serta dokter gigi baik pada tingkat pertama maupun tingkat banding; melakukan penentuan terhadap sanksi disiplin berdasarkan pelanggaran disiplin profesional dokter serta dokter gigi di tingkat pertama maupun tingkat banding; melaksanakan Keputusan MKDKI yang akan dijadikan sebagai kewenangan MKDKI; melakukan pembinaan, pengkoordinasian, serta pengawasan terhadap pelaksanaan tugas dari MKDKI-P; pembuatan serta pemberian pertimbangan terhadap usulan pembentukan MKDKI-P pada KKI; melakukan penyuluhan, sosialisasi, serta diseminasi mengenai MKDKI dan MKDKI-P; melakukan pencatatan serta pendokumentasian pengaduan, proses pemeriksaan, serta Keputusan MKDKI.

Berdasarkan Pasal 4 Peraturan Konsil Kedokteran Indonesia Nomor 50 Tahun 2017 tentang Tata Cara Penanganan Pengaduan Disiplin Dokter dan Dokter Gigi, menyatakan bahwa MKDKI bukanlah lembaga yang dapat melakukan mediasi, rekonsiliasi serta negosiasi antara Pengadu, Teradu, Pasien, dan/ atau kuasanya; MKDKI juga tidak menerima pengaduan yang berhubungan dengan permasalahan etika serta masalah hukum baik itu perdata ataupun pidana; jika pada pemeriksaan dijumpai pelanggaran etika, maka MKDKI akan meneruskan pengaduan tersebut kepada organisasi profesi.

Pelanggaran disiplin profesi dalam Peraturan Konsil Kedokteran Indonesia No. 4 Tahun 2011 tentang Disiplin Profesional Dokter dan Dokter Gigi dapat dikelompokkan menjadi 3, yaitu:

1. Melaksanakan praktik kedokteran yang tidak kompeten;

2. Tugas serta tanggung jawab profesional dokter yang harus diberikan pada pasien tidak dilaksanakan secara baik; dan

3. Melakukan tindakan yang tercela yang dapat merusak martabat serta kehormatan profesi kedokteran.

Pengaduan terhadap adanya dugaan sengketa medis juga tercantum dalam Pasal 66 Undang-Undang Nomor 29 Tahun 2004 tentang Praktik Kedokteran, ayat (1) menyatakan apabila seseorang mengetahui ataupun merasa dirugikan akibat dari tindakan dokter ketika melaksanakan praktik kedokteran dapat mengadukan kepada Ketua Majelis Kehormatan Disiplin Kedokteran Indonesia secara tertulis. Pengaduan ini tidaklah menghilangkan hak seseorang untuk dapat mengadukan adanya dugaan tindak pidana pada pihak berwenang dan/atau melakukan gugatan kerugian perdata di pengadilan.

Berdasarkan Pasal 66 ayat (1) UndangUndang Nomor 29 Tahun 2004 tentang Praktik Kedokteran yang menyatakan bahwa apabila seseorang merasa dirugikan terhadap tindakan kedokteran maka dapat mengadukannya kepada ketua MKDKI. Kata "dapat” yang tercantum dalam ayat (1) tersebut dapat memiliki makna bahwa pengaduan terhadap MKDKI tersebut mungkin saja dapat dilakukan ataupun tidak dilakukan. Sedangkan pada Pasal 3 ayat (2) Peraturan Konsil Kedokteran Indonesia Nomor 4 Tahun 2011 tentang Disiplin Profesional Dokter dan Dokter Gigi, telah menyatakan 
bahwa terdapat 28 bentuk pelanggaran terhadap disiplin profesi, sehinggatelahtercantum dengan jelas bahwa apabila dokter diduga melanggar salah satu dari 28 bentuk pelanggaran disiplin profesi tersebut maka pengaduan harus melalui MKDKI. Sesuai pada Pasal 4 Peraturan Konsil Kedokteran Indonesia No. 4 Tahun 2011 tentang Disiplin Profesional Dokter dan Dokter Gigi menyatakan bahwa untuk menegakan disiplin bagi dokter yang diduga melanggar peraturan yang telah ditetapkan oleh Konsil Kedokteran Indonesia (KKI) maka dokter tersebut dapat diberikan sanksi disiplin yang sesuai dengan ketentuan yang berlaku.

Sedangkan berdasarkan Undang-Undang Nomor 29 Tahun 2004 tentang Praktik Kedokteran telah dikatakan dengan tegas bahwa pemberian sanksi disiplin kepada dokter merupakan wewenang dari MKDKI, hal ini sesuai dengan Pasal 67 Undang-Undang Nomor 29 Tahun 2004 tentang Praktik Kedokteran yang menyatakan bahwa MKDKI-lah yang memeriksa dan membuat keputusan terhadap adanya pengaduan yang berhubungan dengan disiplin profesi dokter. Dan pada Pasal 69 ayat (2) Undang-Undang Nomor 29 Tahun 2004 tentang Praktik Kedokteran mengatakan bahwa keputusan yang dimaksud berupa apakah seorang dokter tersebut dinyatakan bersalah atau tidak bersalah dan diberikan sanksi disiplin. Sanksi disiplin dapat diberikan MKDKI berdasarkan Pasal 69 ayat (3) UndangUndang Nomor 29 Tahun 2004 tentang Praktik Kedokteran dapat berupa:

1 Memberikan sanksi/peringatan tertulis;

2 Memberikan rekomendasi untuk melakukan pencabutan Surat Tanda Registrasi (STR) ataupun Surat Izin Praktik (SIP);

3 Memberikan kewajiban bagi dokter yang dinyatakan bersalah karena telah melanggar disiplin dokter untuk mengikuti pelatihan ataupun pendidikan pada institusi pendidikan kedokteran.

Namun kenyataannya pada Pasal 66 ayat (3) Undang-Undang Nomor 29 Tahun 2004 tentang Praktik Kedokteran menyatakan bahwa pengaduan terhadap Ketua MKDKI tersebut tidak menutup kemungkinan bagi pihak yang dirugikan untuk melaporkan adanya dugaan tindak pidana pada pihak yang berwenang atau menuntut kerugian ke pengadilan. Hal ini mengakibatkan para pihak yang merasa dirugikan oleh tindakan kedokteran dapat langsung membuat pengaduan ke lembaga peradilan dan menimbulkan ketidakpastian hukum. ${ }^{32}$ Karena pada sengketa medis biasanya yang menjadi permasalahannya adalah hasil akhir dari pelayanan kesehatan tanpa memperhatikan prosesnya, padahal berdasarkan hukum, dokter sebagai tenaga medis hanya bertanggung jawab terhadap proses ataupun upaya yang dilakukan (inspaning verbintennis) dan tidak menjamin hasil akhir (resultalte verbintennis). ${ }^{33}$

Setiap melakukan tindakan kedokteran tentunya selalu ada risiko medis yang menyertai dengan tingkatan yang berbeda, baik itu risiko ringan hingga risiko yang dapat menyebabkan kematian. Namun pada kasus tertentu dokter dihadapkan dalam pilihan apakah tindakan kedokteran tersebut tetap harus dilakukan dengan kemungkinan timbulnya risiko atau tidak melakukan suatu tindakan kedokteran yang dapat mengakibatkan kejadian yang tidak diharapkan. Dokter juga merupakan

\footnotetext{
32 Irawati, "INKONSISTENSI REGULASI DI BIDANG KESEHATAN DAN IMPLIKASI HUKUMNYA TERHADAP PENYELESAIAN PERKARA MEDIK DI INDONESIA.”

${ }^{33}$ Bonifasius Nadya Aribowo, B. Resti Nurhayati, and Sofyan Dahlan, "PERSEPSI PASIEN TENTANG ASPEK HUKUM PERIKATAN UPAYA (INSPANNING VERBINTENIS) DALAM TRANSAKSITERAPEUTIK ANTARA DOKTER DENGAN PASIEN DI RSUD KOTA SALATIGA," SOEPRA 3, no. 1 (2017): 52-59, https://doi.org/10.24167/shk.v3i1.696.
} 
manusia biasa yang mungkin saja melakukan kesalahan dalam menjalankan profesinya, baik sengaja (dolus), maupun tidak sengaja (lalai, culpa), maka terkadang keinginan untuk menolong dan menyembuhkan pasien tidak selalu membuahkan hasil yang baik, sehingga dapat memungkinkan timbulnya kecacatan bahkan kematian akibat praktik kedokteran. Sedangkan dalam menyelenggarakan praktik kedokterannya, seorang dokter tidak berniat untuk mencelakakan pasiennya. Sehingga dengan adanya Pasal 66 ayat (3) UndangUndang Nomor 29 Tahun 2004 tentang Praktik Kedokteran dapat menimbulkan ketidakpastian hukum. Karena apabila dokter yang telah diperiksa serta dinyatakan tidak bersalah dalam melakukan pelanggaran disiplin oleh MKDKI, mungkin saja dinyatakan bersalah dalam peradilan pidana dan/atau peradilan perdata. ${ }^{34}$ Oleh karena itu, kata "dapat" yang tercantum dalam ayat (1) tersebut seharusnya diganti menjadi "harus" yang bearti seluruh pengaduan yang berkaitan dengan sengketa medis harus diselesaikan melalui MKDKI terlebih dahulu dan tidak dapat melakukan pengaduan selain melalui MKDKI.

Selama ini pihak yang merasa dirugikan akan lebih memilih membuat pengaduan ke lembaga pengadilan karena menganggap lembaga pengadilan dapat melakukan penyelesaian sengketa medis melalui aspek perdata ataupun pidana, sedangkan MKDKI tidak memiliki kewenangan yang dimiliki oleh lembaga pengadilan tersebut. Hal ini dapat dilihat berdasarkan sanksi yang dapat diberikan oleh MKDKI kepada dokter yang melakukan pelanggaran disiplin tercantum pada Pasal 69 ayat (3) Undang-Undang Nomor 29 Tahun 2004 tentang Praktik Kedokteran dimana sanksi yang diberikan kepada dokter berupa

34 Beni Satria, "PERLINDUNGAN HUKUM TERHADAP DOKTER ATAS DUGAAN MELAKUKAN TINDAK PIDANA MEDIK DIHUBUNGKAN DENGAN AJARAN SIFAT MELAWAN HUKUM MATERIIL," Jurnal Abdi Ilmu 2, no. 1 (2019): 114-22. sanksi disiplin dan dengan adanya Pasal 66 ayat (3) Undang-Undang Nomor 29 Tahun 2004 tentang Praktik Kedokteran, maka dapat terlihat adanya keterbatasan wewenang dari MKDKI yang mengakibatkan kurangnya kekuatan yang mengikat bagi profesinya. ${ }^{35}$

Sehingga apabila kata "dapat" yang tercantum pada Pasal 66 ayat (1) UndangUndang Nomor 29 Tahun 2004 tentang Praktik Kedokteran tersebut diganti menjadi "harus" maka hal ini dapat membuat kompetensi MKDKI menjadi mutlak dan semua permasalahan sengketa medis harus diselesaikan melalui MKDKI, dalam hal ini pengaduan mengenai adanya sengketa medis tidak dapat melalui lembaga pengadilan. Bahkan apabila pengaduan adanya sengketa medis kepada MKDKI merupakan sebuah keharusan, maka apabila terdapat pengaduan ke lembaga pengadilan, lembaga pengadilan tersebut wajib menolak pengaduan tersebut. Hal ini dikarenakan kewenangan terhadap penerimaan pengaduan sengketa medis mutlak berada pada MKDKI.

Seorang dokter yang digugat oleh pasiennya belum tentu dikatakan bersalah ketika pengaduan tersebut masih dalam proses di MKDKI. Hal ini tentu saja dapat menimbulkan kesusahan bagi dokter yang digugat tersebut, selain itu masalah yang dihadapinya akan menjadi rumit apabila masalah tersebut sudah masuk pada media ataupun ranah publik dan dapat mengakibatkan terjadinya pembunuhan karakter yang disebabkan oleh kecenderungan dari pasien yang menyatakan dokter bersalah. Dimana pembunuhan karakter tidak adil bagi dokter yang digugat ke pengadilan. Hal ini dikarenakan belum tentu dokter tersebut bersalah sedangkan karirnya sudah jelek di mata masyarakat. ${ }^{36}$

${ }^{35}$ Mudakir Iskandar Syah, Tuntutan Hukum Malpraktik Medis, Cetakan 1 (Jakarta: PT. Bhuana Ilmu Populer, 2019).

36 Mulyadi, "Alternatif Penyelesaian Sengketa 
Sebagaimana kasus sengketa medis yang terjadi pada dr. TS dan dr. FMK di RS K Jakarta Pusat pada Februari 2010, mengakibatkan RS K diadukan ke MKDKI pada tanggal 10 Agustus 2010. Setelah 23 bulan pemeriksaan perkara, pada 26 Juni 2012, MKDKI mengeluarkan keputusan pada pengaduan Siti Chomsatun yang bernomor: No. 43/P/MKDKI/VIII/2010. Berdasarkan keputusan MKDKI, dr. TS dan dr. FMK dinyatakan melakukan pelanggaran disiplin kedokteran yang merujuk pada Pasal 3 ayat (2) huruf f Perkonsil 4 Tahun 2011 tentang Disiplin Profesional Dokter dan Dokter Gigi, yaitu:

1. Pada pasien dengan sesak napas yang dikarenakan lumpuhnya pita suara dr. TS memberikan pengobatan kortikosteroid, sedangkan dalam putusan MKDKI a quo, pemberian kortikosteorid tersebut tidak lazim bagi pasien keluhan sesak nafas yang dikarenakan kelumpuhan dari pita suara, seharusnya penanganan yang diberikan kepada Siti Chomsatun berupa tindakan observasi ketat.

2. dr. FMK meresepkan obat antihipertensi (captopril) pada kertas resep yang bukan miliknya sendiri.

Berdasarkan putusan MKDKI tersebut, Siti Chomsatun melakukan Gugatan Perbuatan Melawan Hukum kepada RS K ke Pengadilan Negeri Jakarta Pusat. Melalui Putusan Pengadilan Negeri Jakarta Pusat nomor 287/ Pdt.G/2017/PN.Jkt.Pst hakim mengabulkan serta memutuskan untuk memberi ganti rugi secara materil pada Siti Chomsatun sebesar Rp. 17.620.933, 00 yang wajib dibayar pihak tergugat. ${ }^{37}$

Oleh karena itu, sangat diharapkan bahwa MKDKI dapat dijadikan sebagai langkah

Kelalaian Medik yang Berkeadilan di Indonesia." Journal of Multidisciplinary Studies 11, no. 2 (December 2020): 126-38.

${ }^{37}$ Sjahdeini, HUKUM KESEHATAN TENTANG “HUKUM MALAPRAKTIK TENAGA MEDIS” Jilid 2. awal bagi pihak yang bersengketa sebelum lanjut ke proses pengadilan. Keputusan yang telah ditetapkan oleh MKDKI juga harus ditegaskan apakah keputusan dari MKDKI ini dapat dijadikan bukti awal bahwa seorang dokter telah melakukan pelanggaran disiplin kedokteran khususnya kelalaian. Mengenai sanksi yang dapat diberikan oleh MKDKI untuk dokter yang melanggar disiplin kedokteran harus dipertimbangkan lagi apakah MKDKI dapat menentukan ganti rugi pada pihak yang sedang bersengketa. Hal ini dikarenakan dalam penyelesaian sengketa medis bersifat lex spesialis derogat lex generali maka MKDKI diharapkan dapat melakukan penyempurnaan agar lebih memberikan kepastian hukum dan keadilan bagi semua pihak. $^{38}$

\section{PENUTUP}

Penyelesaian sengketa medis seharusnya melalui MKDKI, karena MKDKI-lah yang memahami penerapan disiplin profesi ketika seorang dokter menyelenggarakan praktik kedokteran, dan MKDKI juga merupakan lembaga yang berwenang untuk menentukan ada atau tidaknya pelanggaran terhadap disiplin profesi yang dilakukan dokter. Kata "dapat" pada Pasal 66 ayat (1) Undang-Undang Nomor 29 Tahun 2004 tentang Praktik Kedokteran dapat memiliki makna bahwa pengaduan terhadap MKDKI tersebut dapat dilakukan ataupun tidak dilakukan. Ketidakpastian hukum dapat timbul, sehingga Kata "dapat" tersebut seharusnya diganti menjadi "harus" yang bearti pengaduan sengketa medis harus diselesaikan melalui MKDKI terlebih dahulu. Sehingga perlu dilakukannya judicial review terhadap Pasal 66 ayat (1) Undang-Undang Nomor 29 Tahun 2004 tentang Praktik Kedokteran, dan perlu dipertimbangkan apakah MKDKI dapat menentukan ganti rugi kepada pihak yang

${ }^{38}$ Mulyadi, "Alternatif Penyelesaian Sengketa Kelalaian Medik yang Berkeadilan di Indonesia." 
sedang bersengketa. Sehingga setiap putusan dari MKDKI dapat memberikan kepastian hukum bagi dokter dan masyarakat.

\section{DAFTAR PUSTAKA}

Andryawan. "Kedudukan Majelis Kehormatan Disiplin Kedokteran Indonesia (MKDKI) Dan Konsil Kedokteran Indonesia (KKI) Dalam Penegakan Disiplin Kedokteran Di Indonesia (Studi Putusan Mahkamah Agung RI Nomor: 298K/TUN/2012)." Thesis, Universitas Tarumanegara, 2015.

Aribowo, Bonifasius Nadya, B. Resti Nurhayati, and Sofyan Dahlan. "PERSEPSI PASIEN TENTANG ASPEK HUKUM PERIKATAN UPAYA (INSPANNING VERBINTENIS) DALAM TRANSAKSI TERAPEUTIK ANTARA DOKTER DENGAN PASIEN DI RSUD KOTA SALATIGA." SOEPRA 3, no. 1 (2017): 52-59. https:// doi.org/10.24167/shk.v3i1.696.

Ariefana, Pebriansyah, andUmmiHadyah Saleh. "Keluarga Korban Malpraktik Falya Raafani Blegur Mengadu Ke KY.” Suara. Com, February 3, 2017. https://www. suara.com/news/2017/02/03/140634/ keluarga-korban-malpraktik-falyaraafani-blegur-mengadu-ke-ky?page=all.

Bachtiar. Metode Penelitian Hukum. Cetakan Pertama. UNPAM PRESS, 2019.

Fadly, Moh. "Putusan MKDKI Sebagai Bukti Permulaan Dalam Proses Penyidikan Terhadap Dokter Yang Dilaporkan Dalam Sengketa Medik." Thesis, Univesitas Islam Indonesia, 2017.

Gunawan, Juliana Susanti. "Living Law Transplantation In Construction Criminal Medical Law." Nagari Law Review 4, no. 2 (April 2021): 188-99.

Hartiningsih, Retno Harjanti. "POLA HUBUNGAN HUKUM ANTARA
DOKTER DAN PASIEN." MAKSIGAMA 14, no. 1 (July 27, 2020): 49-60. https:// doi.org/10.37303/maksigama.v14i1.88.

Hidayat, Sabrina. Pembuktian Kesalahan: Pertanggungjawaban Pidana Dokter Atas Dugaan Malpraktik Medis. Scopindo Media Pustaka, 2020.

Irawati, Jovita. "INKONSISTENSI REGULASI DI BIDANG KESEHATAN DAN IMPLIKASI HUKUMNYA TERHADAP PENYELESAIAN PERKARA MEDIK DI INDONESIA." Law Review 19, no. 1 (July 2019): 54-76. https://doi. org/10.19166/lr.v19i1.1551.

Irfan, Mohammad, and Syamsul Hidayat. "SENGKETA MEDIK DAN ALTERNATIF PENYELESAIANNYA DALAM HUKUM POSITIF DI INDONESIA." Jurnal IUS Kajian Hukum dan Keadilan 6, no. 3 (December 26, 2018): 482-92. https://doi.org/10.29303/ius.v6i3.572.

Jauhani, MuhammadAfiful. Dilema Kapabilitas Dan Imparsialitas Dokter Sebagai Mediator Sengketa Medis. Surabaya: Scopindo Media Pustaka, 2020.

Majelis Kehormatan Etik Kedokteran. Pedoman Organisasi Dan Tatalaksana: Majelis Kehormatan Etik Kedokteran Ikatan Dokter Indonesia. Samarinda: MKEK IDI, 2018.

Mannas, Yussy A. "Hubungan Hukum Dokter dan Pasien Serta Tanggung Jawab Dokter Dalam Penyelenggaraan Pelayanan Kesehatan." JURNAL CITA HUKUM 6, no. 1 (June 23, 2018): 163-82. https://doi. org/10.15408/jch.v6i1.8274.

Muhaimin. Metode Penelitian Hukum. Cetakan Pertama. NTB: Mataram University Press, 2020.

Mulyadi, Deri. “Alternatif Penyelesaian Sengketa Kelalaian Medik yang Berkeadilan di Indonesia." Journal of Multidis- 
ciplinary Studies 11, no. 2 (December 2020): 126-38.

Novianto, Widodo Tresno. SENGKETA MEDIK Pergulatan Hukum Dalam Menentukan Unsur Kelalaian Medik. Cetakan 1. Surakarta: Penerbitan dan Percetakan UNS (UNS Press, 2017.

Nugrianti, Khairunnisa, and Ratna Herawati. "TINJAUAN YURIDIS TUGAS DAN WEWENANG MAJELIS KEHORMATAN DISIPLIN KEDOKTERAN INDONESIA" 6, no. 2 (2017): 1-18.

Radar Sulteng. "Dugaan Malapraktik, Dr Heryani Menangis Bacakan Pembelaan Pribadinya," May 31, 2018. https:// radarsulteng.id/dugaan-malapraktik-drheriyani-menangis-bacakan-pembelaanpribadinya/.

Riyanto, Ontran Sumantri. Pembentukan Pengadilan Khusus Medis. Cetakan Pertama. Surabaya: Deeppublish Publisher, 2018.

Salbiah, Nurul Adriyana. "Hari Kesadaran Hukum Kedokteran, Ada 3 Catatan Kriminalisasi Dokter," June 30, 2018. https://www. jawapos.com/kesehatan/30/06/2018/ hari-kesadaran-hukum-kedokteran-ada3-catatan-kriminalisasi-dokter/.

Santoso, Arif Dian. "PENYELESAIAN SENGKETA MEDIK MELALUI MEDIASI OLEH MAJELIS KEHORMATAN DISIPLIN KEDOKTERAN INDONESIA (MKDKI) UNTUK DAPAT MENJAMIN KEADILAN DALAM HUBUNGAN DOKTER DAN PASIEN." Jurnal Pasca Sarjana Hukum UNS 7, no. 1 (2019): 29-38.

Saputra, Afendra Eka. "PERLINDUNGAN HUKUM BERBASIS 'INFORMED CONSENT' ATAS PELAKSANAAN PROGRAM IMUNISASI DI INDONESIA." Rechtsregel : Jurnal Ilmu Hukum
1, no. 2 (January 29, 2019): 235-54. https://doi.org/10.32493/rjih.v1i2.2216.

Sari, Nursita. "Bayinya Meninggal Di RS, Ibu Ini Laporkan Dokter Di Bekasi Ke Polisi." Kompas.Com, March 28, 2017. https://megapolitan.kompas.com/ $\mathrm{read} / 2017 / 03 / 28 / 15185181 /$ bayinya. meninggal.di.rs.ibu.ini.laporkan.dokter. di.bekasi.ke.polisi?page=all.

Satria, Beni. "PERLINDUNGAN HUKUM TERHADAP DOKTER ATAS DUGAAN MELAKUKAN TINDAK PIDANA MEDIK DIHUBUNGKAN DENGAN AJARAN SIFAT MELAWAN HUKUM MATERIIL." Jurnal Abdi Ilmu 2, no. 1 (2019): 114-22.

Situmorang, Risma. Tanggungjawab Hukum Dokter Dalam Malpraktik. Bandung: CV Cendekia Press, 2020.

Sjahdeini, Sutan Remy. HUKUM KESEHATAN TENTANG "HUKUM MALAPRAKTIK TENAGA MEDIS” Jilid 2. Cetakan 1. Bogor: PT. Penerbit IPB Press, 2020.

Sugiharto, Setyo. "Negosiasi Sebagai Alternatif Penyelesaian Sengketa Medik Dalam Perspektif Pemenuhan Hak Pasien." Thesis, Universitas Muhammadiyah Malang, 2020.

Supriyatin, Ukilah. "HUBUNGAN HUKUM ANTARA PASIEN DENGAN TENAGA MEDIS (DOKTER) DALAM PELAYANAN KESEHATAN." Jurnal Ilmiah Galuh Justisi 6, no. 2 (November 19, 2018): 184-94. https://doi.org/10.25157/ jigj.v6i2.1713.

Syah, Mudakir Iskandar. Tuntutan Hukum Malpraktik Medis. Cetakan 1. Jakarta: PT. Bhuana Ilmu Populer, 2019. 